\title{
Sari Karttunen
}

\section{VALTIONAVUSTUKSET KULTTUURIPOLITIIKAN OHJAUSVÄLINEINÄ}

\author{
Huomioita opetus- ja kulttuuriministeriölle tehdystä pika- \\ analyysistä
}

\section{State grants as cultural policy steering instruments. Notions on a quick analysis assignment for the Ministry of Education and Culture}

\begin{abstract}
The text draws upon an assignment carried out by the Foundation for Cultural Policy Research (Cupore) for the Finnish Ministry of Education and Culture. The task was to map out the system of discretionary grants in cultural policy to point out weaknesses in strategic goal setting and attainment. The commission was motivated by the pressure to demonstrate effectiveness within the framework of the state management and steering system. The mapping was focused on grants that the Ministry allocates under the rubric 'arts and culture'. This concerns some 50 different grant forms, amounting to EUR 55 million in 2013. The Cupore research team looked into details in the grant allocation practices, e.g., formulations of grant targets in the calls for application and wordings on the application forms. We also made an e-mail questionnaire on the presenting officers. It was concluded that discretionary grants in culture make up rather an incoherent and heterogeneous system. Some grant forms derive from the 19th century, prior to any cultural policy proper, while others are the product of recent targeted programmes. The strategy for cultural policy launched by the Ministry in 2009 was reflected only in places in the grant system. It was moreover noted that the goals of cultural policy were not entirely clear to provide basis for assessment of effectiveness. The policy sector emerged in many respects as a silo resisting alignment with renewed state management and steering methods. Several suggestions were made to the Ministry to control effectiveness, e.g., improved communication of grant policy goals, target guidance schemes with major grant recipients and co-ordination of grants as part of the cultural policy tools system.
\end{abstract}

\section{Tausta ja tavoitteet}

Pohdintani perustuu Kulttuuripoliittisen tutkimuksen edistämissäätiössä (Cuporessa) opetusja kulttuuriministeriön (OKM) toimeksiannosta vuonna 2014 tehtyyn selvitykseen, jossa tarkasteltiin kulttuurialan valtionavustustoimintaa strategisuuden ja vaikuttavuuden näkökulmasta. Kysymys oli siitä, saako OKM valtionavustusten kautta toteutettua kulttuuripolitiikalle asetettuja tavoitteita. Kulttuuri- ja taidepolitiikan osasto tilasi selvityksen taustamateriaaliksi työryhmälle, joka pohti koko ministeriön valtionavustustoimintaa. Selvityksen aikataulu oli tästä johtuen tiukka, ja toimeksiantajan esityksestä siinä keskityttiin osaston omiin avustuskäytäntöihin. Hankkeessa analysoitiin ministeriössä laadittuja valtionavustusten hakuilmoituksia ja ohjeita sekä hakijoiden sinne toimittamaa aineistoa, lähinnä avustushakemuksia ja avustuksen käytöstä tehtyjä selvityksiä.

Kulttuuri- ja taidepolitiikan osasto $^{1}$ toivoi selvitykseltä pikemmin olemassa olevien käytäntöjen kriittistä arviointia kuin uusien mallien esittämistä. Cupore katsottiin tehtävään 
sopivaksi, koska se on erikoistunut kulttuuripolitiikan sektoritutkimukseen ja tekee paljon OKM:öön liittyvää selvitystyötä ${ }^{2}$ Yksityisen säätiön ylläpitämänä tutkimuskeskuksena Cuporella ajateltiin toisaalta olevan riittävästi etäisyyttä ministeriön käytäntöihin. Toimeksianto toi OKM:n ja Cuporen kanssakäymiseen konsultoinnin sävyä. Kyse oli uudentyyppisestä "pika-analyysistä", jossa käydään lyhyessä ajassa läpi suuri määrä materiaalia ja tehdään huomioita sisäisen kehittämistyön pohjaksi. Raportoimme tulokset suullisesti hankkeen toisena vastuullisena tutkijana toimineen Pasi Saukkosen kanssa taide- ja kulttuuripolitiikan osaston kehittämisseminaarissa kesäkuussa $2014^{3}$. Kun osasto päätyi lokakuussa 2014 asettamaan työryhmän pohtimaan toimialan valtionavustusten kehittämistä, koostimme sitä varten keskeiset huomiomme kirjalliseen muotoon (Karttunen, Kontkanen \& Saukkonen, 2014).

Tuon tässä tekstissä julki valtionavustushankkeessa tehtyjä kulttuurin ohjausjärjestelmää koskevia havaintoja, joilla uskon olevan merkitystä kulttuuripolitiikan tutkimuksen kannalta. OKM:lle toimitettua käsikirjoitusta ei ole julkisesti saatavilla painettuna tai nettijulkaisuna. Se on tietosisällöltään ja kirjoitusasultaan joiltain osin viimeistelemätön mutta riittävä palvelemaan toimeksiantajan tarpeita. Arvelen, että alan tutkijoita kiinnostaa myös saada tietoa sektoritutkimuslaitoksen ja kulttuurihallinnon välisestä suhteesta, jota hankkeen kuvaus osaltaan raottaa. Kerron seuraavaksi toimeksiannon toteutuksesta ja tiivistän sen keskeisiä tuloksia. Sen jälkeen pohdin näiden tulosten sekä selvitysprosessin aikana tekemiemme havaintojen merkitystä kulttuurin julkisen ohjauksen ja sen tutkimuksen kannalta.

\section{Selvityksen toteutus}

OKM:lle tehdyssä selvityksessä arvioitiin 41:tä kulttuurialan valtionavustusta. Joukkoon päädyttiin seuraavasti: Ensinnäkin rajauduttiin niihin valtionavustuksiin, joissa ministeriö itse toimii valtionapuviranomaisena, koska ensisijaisena tarkoituksena oli palvella sisäistä kehit- tämistä. OKM on delegoinut merkittävän osan kulttuuribudjettiin sisältyvistä valtionavustuksista alaisilleen virastoille ja kolmannen sektorin toimijoille ${ }^{4}$. Toiseksi määriteltiin kohteeksi ne valtionavustukset, jotka lueteltiin selvityshetkellä OKM:n verkkosivulla otsikon "kulttuuriin ja taiteeseen liittyvät avustukset" alla. Tällöin ulkopuolelle jäivät yhtäältä kirjasto- ja tekijänoikeusalan avustukset ja toisaalta ei-julkisessa haussa olevat avustukset ${ }^{5}$. Verkkosivulla mainittiin vuonna 2013 kaikkiaan 49 eri avustusmuotoa. Niistä poistettiin eri syistä kahdeksan, jolloin tarkasteltavaksi jäi 41 avustusmuotoa (Taulukko 1) ${ }^{6}$.

Seuraavaksi tehtiin numeerinen katsaus vuoden 2013 talousarviossa avustusmuotoihin varattuihin määrärahoihin sekä niihin kohdistuneisiin hakemuksiin ja myöntöihin. Valtaosa avustusmuodoista rahoitetaan taiteen veikkausvoittovaroista (valtion talousarvion momentti 29.80.52). Tiedot saatiin OKM:n valtionavustusten käsittelyjärjestelmästä (Salama), verkkosivuilta sekä virkamiehiltä7. Tämän jälkeen selvitettiin avustusmuotoihin kytkettyjä kulttuuripoliittisia tavoitteita sekä avustusten haku- ja myöntöproseduureja. Keskeinen lähde kulttuuripoliittisten tavoitteiden tunnistamiseksi olivat avustusten hakuilmoitukset liitteineen ja linkkeineen. Tiedot kerättiin OKM:n verkkosivuilta marras-joulukuun vaihteessa $2013^{8}$. Tämän jälkeen esitteleviltä virkamiehiltä kysyttiin sähköpostitse tarkennusta siihen, mitä dokumentteja ja linjauksia he pitivät olennaisina vastuullaan olevien avustusten kannalta. Niin ikään heiltä tiedusteltiin avustuskäytäntöjen viimeaikaisista tai vireillä olevista uudistuksista. Kukin esittelijä vastaa oman alansa avustusten haettavaksi julistamisesta ja siihen liittyvien ohjeiden, hakuoppaiden ja verkkosivujen päivittämisestä ja oikeellisuudesta. Toimintaa ohjaa OKM:n menettelytapaohje ${ }^{9}$.

Kartoitusvaiheen jälkeen otettiin tarkempaan analyysiin kuusi avustusmuotoa, jotka oli tarkoitettu seuraaviin kohteisiin: 1) valtakunnalliset kuvataidealan järjestöt, 2) valtakunnalliset erikoismuseot, 3) lastenkulttuurikeskukset, 4) kulttuuriviennin kärkihankkeet, 5) valtakunnalliset taide- ja kulttuuritapahtumat sekä 6) 
Suomen ulkomailla toimivat kulttuuri-instituutit. Tapausaineistoon sisällytettiin avustushakemukset sekä avustuksen käytöstä ministeriölle tehdyt käyttöselvitykset, jotka koskivat vuodelle 2010 myönnettyjä avustuksia ${ }^{10}$. Aineisto saatiin OKM:n arkistosta. Avustuksensaajien raporteissa keskityttiin siihen, mitä niissä esitettiin toiminnan keskeisinä tuloksina ja kuinka nämä vastasivat avustusmuodolle asetettuja tavoitteita. Lisäksi kartoitettiin sitä, tuotiinko asiakirjoissa esille toiminnan vaikutuksia toteuttavan organisaation ulkopuolella. Alun perin hankkeeseen oli tarkoitus sisältyä yhteydenottoja avustuksensaajiin, mutta tästä luovuttiin kireän aikataulun takia.

Aineiston analyysissa hyödynnettiin paitsi Cuporen omia aiempia selvityksiä tapauksiksi valituista avustusmuodoista, myös OKM:n ja Taiteen keskustoimikunnan (TKT:n) tekemiä tai teettämiä selvityksiä ja arviointeja. Kulttuuritapahtumista oli olemassa Pauli Rautiaisen (2010) tutkimus sekä OKM:n (2011a) asettaman työryhmän raportti, ja tuoretta aineistoa saatiin Cuporessa tekeillä olleesta Kulttuuritapahtumien kulttuuripoliittinen ja aluetaloudellinen vaikuttavuus -hankkeesta (2014-2015). Lastenkulttuurikeskusten tapauksessa voitiin viitata OKM:n teettämiin arviointeihin (Granö, Korkeakoski \& Laukka, 2006; Korkeakoski \& Pääjoki, 2009). Kalle Kallion (2012) selvitys sivuaa erikoismuseoavustusta. Kulttuuriviennin kärkihankeavustus taas liittyy kiinteästi kulttuuriviennin kehittämisohjelmaan 2007-2011 ja sen ohjeistusta on rukattu ohjelman loppuraportin (2011) pohjalta (Aulake, sähköposti, 10.12.2013). Kulttuuri-instituuttien tapauksessa nojattiin Kontkasen, Saukkosen ja Mitchellin (2012) Cuporessa laatimaan selvitykseen, jossa aineistona käytettiin sekä avustushakemuksia että haastatteluita.

Aineistonkeruu- ja analyysivaiheiden jälkeen tutkijaryhmä muodosti diagnoosia siitä, missä valtionavustustoiminnan kohdissa OKM:llä näyttää olevan ongelmia strategisuudessa ja vaikuttavuuden kontrolloinnissa. Lopuksi tehtiin myös joukko kehittämisehdotuksia, joista keskusteltiin toimeksiantajan kanssa sekä ohjausryhmän palavereissa että kulttuuri- ja tai- depolitiikan osaston seminaarissa kesäkuussa $2014^{11}$. Osaston pyydettyä syksyllä 2014 kirjallista raporttia päätelmiä ja ehdotuksia työstettiin ja joitakin asiatietoja tarkistettiin. Tällöin tutkijoilla oli jo käytettävissään luonnos koko OKM:n valtionavustustoimintaa pohtineen työryhmän raportista, joka julkaistiin marraskuussa 2014 (Opetus- ja kulttuuriministeriö, 2014). Kulttuuri- ja taidepolitiikan osasto asetti lokakuussa 2014 työryhmän selvittämään toimialan valtionavustuspolitiikan kehittämistä ja uudistamista $^{12}$. Sen on määrä jättää raporttinsa joulukuussa 2015.

\section{Selvityksen keskeiset käsitteet}

\section{Valtionavustus}

Valtionavustuksella tarkoitetaan valtion varoista myönnettävää rahoitusta, jolla tuetaan yhteiskunnallisesti hyödylliseksi katsottavaa toimintaa tai hanketta. Valtionavustuksia myönnetään kirjallisen hakemuksen perusteella valtion talousarvioon otetuista määrärahoista. Kustakin määrärahasta voidaan julistaa auki hakuja, joissa määritellään myönnettävien avustusten käyttötarkoitus, myöntökriteerit sekä muut hakemiseen ja myöntämiseen liittyvät seikat. (Valtiontalouden tarkastusvirasto, 2004, s. 12; Opetus- ja kulttuuriministeriö, 2014, s. 10.)

Valtionavustusten myöntämisessä sovelletaan valtionavustuslakia (688/2001), joka on yleislaki. Valtionavustuksia myönnetään myös erityislainsäädännön perusteella, mistä esimerkkinä kulttuurin alueelta voidaan mainita laki opetus- ja kulttuuritoimen rahoituksesta (1705/2009). Jos määrärahaa koskee erityislaki, noudatetaan ensisijaisesti sitä. Valtionavustus voidaan myöntää yleisavustuksena tai erityisavustuksena. Yleisavustus on tarkoitettu hakijan toimintaan yleisesti tai osaan siitä, kun taas erityisavustus myönnetään tiettyyn hankkeeseen tai kohteeseen ${ }^{13}$.

Avustuksen myöntäminen sekä sen määrä ja käyttötarkoitus perustuvat viranomaisen harkintavaltansa nojalla tekemään päätökseen. Valtionapuviranomaisen tulee lain mukaan varmistua seuraavista seikoista: 
1) tarkoitus, johon valtionavustusta haetaan, on yhteiskunnallisesti hyväksyttävä,

2) valtionavustuksen myöntäminen on perusteltua valtionavustuksen käytölle asetettujen tavoitteiden kannalta,

3) valtionavustuksen myöntämistä on pidettävä tarpeellisena, kun otetaan huomioon hakijan saama muu julkinen tuki sekä valtionavustuksen kohteena olevan hankkeen tai toiminnan laatu ja laajuus, ja

4) valtionavustuksen myöntämisen ei voida arvioida aiheuttavan muita kuin vähäisiä markkinoiden toimintaa ja kilpailua vääristäviä vaikutuksia Euroopan talousalueeseen kuuluvassa valtiossa.

Valtionavustuslaissa säädetään myös vaikutusten arvioinnista ${ }^{14}$, mikä osaltaan motivoi Cuporen OKM:stä saamaa toimeksiantoakin. Valtionapuviranomaisen on seurattava myöntämiensä avustusten käytön tuloksellisuutta ja tarkoituksenmukaisuutta. Samoin tulee tarkkailla valtionavustusten vaikutuksia kilpailuun, eri väestöryhmien asemaan sekä niiden ympäristö- ja muita vaikutuksia. Valtionavustusten tarpeellisuutta ja kehittämistarpeita on arvioitava määräajoin.

Valtionavustukset ovat "erottamaton osa OKM:n ohjausjärjestelmää" (Opetus- ja kulttuuriministeriö, 2014, s. 11). Useimmilla muilla toimialoilla niillä ei ole yhtä keskeinen rooli. Osa valtionavustuksista on valtion talousarviossa tai erityislainsäädännössä tiukasti sidottuja, mutta osa tarjoaa ministeriölle mahdollisuuden kohdistaa voimavaroja joustavasti tärkeisiin ja ajankohtaisiin tarkoituksiin. Valtiontalousarviossa vuodelle 2013 valtionavustukset olivat OKM:n pääluokassa yhteensä noin 2,5 miljardia euroa (emt.). Taiteen ja kulttuurin toimialan rahoitus oli vajaat 452 miljoonaa euroa, josta valtionavustuksia oli 223 miljoonaa (51,5 \%) (emt., 16$)^{15}$.

\section{Vaikuttavuus}

Toimeksiannossa keskeinen vaikuttavuuden käsite pyrittiin määrittelemään yhteensopivasti valtiontalouden ohjaus- ja arviointikehikon kanssa. Tässä puhunnassa vaikuttavuus tarkoittaa yhteiskuntapolitiikalle asetettujen tavoitteiden saavuttamista. Vaikuttavuudella ei siis tarkoiteta toiminnan kaikkia mahdollisia vaikutuksia vaan käsite kytketään politiikkatavoitteisiin (vrt. Rajahonka, 2013, s. 12). Kulttuuripolitiikan vaikuttavuuden pohdinnassa nojattiin ennen muuta OKM:n julkaisuun $\mathrm{Vai}$ kuttavuusindikaattorit kulttuuripolitiikan tietopohjan vahvistajina (2009b). Aineksia saatiin myös Mervi Rajahongan (2013) kolmannen sektorin toimijoille suunnatusta oppaasta Vuorovaikutuksessa vaikuttamiseen.

Vaikuttavuus on valtiontalouden ohjaus- ja arviointikehikon ja tulosohjausmallin ydinkäsitteitä. Valtion talousohjaus- ja tilivelvollisuusuudistus 2000-luvun alussa mullisti mallin, jonka avulla tulostavoitteita asetetaan ja tuloksellisuutta raportoidaan. Tulosohjauken keskeiset käsitteet, kuten tuottavuus ja tehokkuus, esitetään ns. tulosprisman avul$\mathrm{la}^{16}$. Tämän kannallaan seisovan kolmion kärkeen sijoittuu "yhteiskunnallinen vaikuttavuus", joka on julkisyhteisöjen toiminnan perimmäinen päämäärä. Yhteiskunnallisen vaikuttavuuden tavoitteet kuvaavat sitä yhteiskunnan tilaa, johon politiikalla halutaan päästä. Tällöin puhutaan sellaisista asioista kuin yhteiskunnallinen rauha ja vakaus tai taloudellinen kasvu ja hyvinvointi (Valtiovarainministeriö, 2003, s. 61). Näistä laajoista vaikuttavuustavoitteista johdetaan toiminnalliset tulostavoitteet, joita on eri alojen ministeriöillä sekä ennen muuta niiden alaisilla virastoilla ja laitoksilla. Käytännössä yhteiskunnallisen vaikuttavuuden ymmärretään syntyvän lukuisten toimijoiden toiminnallisten tulosten summana ja viime kädessä poikkihallinnollisena yhteistyönä. (Valtiovarainministeriö, 2006, s. 15.)

\section{Kulttuurin toimialan valtionavustustoiminnan vaikuttavuus}

Cuporen toimeksiannossa ei ollut kyse niinkään laaja-alaisesta yhteiskunnallisesta kuin suppeammasta kulttuuripoliittisesta vaikuttavuudesta. Valtion konserniohjauksen näkökulmasta kulttuuripolitiikan tulee toki palvella hallitusohjelmassa määriteltyjä yhteisiä tavoitteita. Val- 
tion konserniohjausta on viime vuosina pyritty voimistamaan, ja myös OKM on teettänyt omaa konserniaan koskevan selvityksen (Valtiovarainministeriö, 2012; Opetus- ja kulttuuriministeriö, 2011c). Valtion ohjausmallissa yhteiskunnallisten vaikuttavuustavoitteiden perusta on hallitusohjelmassa, joka annetaan tiedoksi eduskunnalle. Tavoitteita konkretisoidaan strategista toimeenpanoa ohjaavassa asiakirjassa. Eduskunnan kullekin vuodelle hyväksymässä valtion talousarviossa ilmaistaan kunkin hallinnonalan tulos- ja vaikuttavuustavoitteet.

Kulttuurin toimialan valtionavustustoiminnan vaikuttavuus ymmärrettiin selvityksessä tarkoittamaan sitä, edistääkö valtionavustusten myöntäminen - ja niiden turvin toteutettu toiminta - kulttuuripolitiikalle asetettujen tavoitteiden saavuttamista. Arviointiasetelma vaikuttaa yksinkertaiselta, mutta kulttuuripolitiikan tapauksessa haasteena on tavoitteiden identifioiminen. Niiden jäsentymättömyys on noussut ongelmaksi aiemmissakin hankkeissa (ks. esim. Opetusministeriö, 2009b, s. 10-11). OKM itse laati vuonna 2009 Kulttuuripolitiikan strategia 2020 -nimisen asiakirjan, joka pyrki nimenomaan kirkastamaan hallinnonalan "tahtotilaa”. Siinä kulttuuripolitiikan yhteiskunnallisen vaikuttavuuden tavoitteiksi määritellään 1) kulttuurin perustan vahvistaminen, 2) luovan työn tekijöiden toimintaedellytysten parantaminen, 3) kaikkien väestöryhmien kulttuuriin osallistumismahdollisuuksien tukeminen sekä 4) kulttuurin talouden ja luovan talouden vahvistaminen. (Opetusministeriö, 2009a.)

OKM:n verkkosivuilla mainitaan kaksi valtioneuvostotason ohjausasiakirjaa kulttuuripolitiikan toimialalla: taide- ja taiteilijapolitiikkaa koskeva periaatepäätös (2003) ja kulttuurin tulevaisuutta koskevaa selonteko (2011). Kulttuurialan tavoitteita kirjataan tietenkin koko OKM:tä koskeviin strategia-asiakirjoihin, ja useilla taiteen ja kulttuurin osa-alueilla on laadittu kulttuuriosaston siipien alla erillisiä kehittämis- ja toimenpideohjelmia. Jotkin ohjelmista ovat poikkihallinnollisia, kuten kulttuurivientiä koskeva kehittämisohjelma vuodelta 2007. Kulttuuripolitiikan strategia 2020 kokosi hajallaan olevia kulttuuripoliittisia tavoitteita. Strategian status on kuitenkin erikoinen siitä näkökulmasta, että se on laadittu OKM:ssä virkamieslähtöisesti eikä sitä ole viety valtioneuvostoon tai eduskuntaan. Strategiaa ei myöskään ole päivitetty hallituksen vaihtuessa.

Kulttuuripoliittinen ohjaus ei ole valtionavustusten tapauksessa aivan mutkatonta. Tulosprismamalli koskee valtion tulosohjauksen piirissä olevaa toimintaa, kuten valtion virastoja ja laitoksia; OKM ja Taike esimerkiksi tekevät vuosittain tulossopimuksen. Tulosohjauksen ulkopuolella olevien toimijoiden strategiselle ohjaukselle ei ole selkeää mallia (ks. Opetus- ja kulttuuriministeriö, 2014, s. 21). Tällaisia toimijoita on paljon juuri kulttuurin toimialalla. Järjestö-, yhdistys- ja kansalaistoiminnan suhteen OKM nojaa valtionavustuksiin ja niihin liitettyyn informaatio-ohjaukseen. Eräiden suurta, säännöllistä avustusta saavien tahojen kanssa järjestetään tuloskeskusteluja muistuttavia mutta löyhemmin sitovia tavoitekeskusteluja (emt.). Joskus tämän tyyppiseen toimintaan viitataan termillä tavoiteohjaus, mutta sen käyttö ja merkitys ovat vakiintumattomia.

\section{Havainnot ja kehittämisehdotukset}

\section{Numeerinen kuvaus valtionavustustoiminnasta}

Tarkastelun kohteena olleisiin 41 avustusmuotoon käytettiin vuonna 2013 yhteensä lähes 55 miljoonaa euroa. Valtionavustuksia myönnettiin yhteensä 1066 kappaletta. Lukumäärältään ne käsittivät 75 prosenttia OKM:n kulttuurialalla myöntämistä avustuksista mutta euroissa mitattuna osuus jäi 29 prosenttiin ${ }^{17}$. Ero johtuu mm. siitä, että rajauksen ulkopuolelle jäi ei-julkisesti haettavina muutamia isoja avustuksia, kuten Suomen Kansallisteatterin osakeyhtiön ja Suomen Kansallisoopperan säätiön toiminta-avustukset (yhteensä liki 50 milj. euroa). Tarkastellut määrärahat vaihtelivat 23 000 eurosta lähes 6,7 miljoonaan euroon (keskiarvo noin 1,3 milj. euroa) (Taulukko 1). Määrärahoista pienin oli varattu maailmanperintökohteiden tutkimus- ja valistustoimintaan ${ }^{18}$, suurin kulttuuritilojen peruskorjauksiin ja 
perustamishankkeisiin.

Hakemuksia tarkasteltuihin avustusmuotoihin kohdistui yhteensä yli 2000 . Lukumäärä vaihteli 3:sta 238:aan (keskiarvo 52) ja läpimenoprosentti 3:sta 100:aan (keskiarvo 69). Vaikeinta oli saada avustusta kuntien kulttuuritoiminnan kehittämis- ja kokeilutehtäviin: 159 hakemuksesta meni läpi vain 4 (yhteensä 106000 euroa). Kymmenessä avustusmuodossa myöntöprosentti oli sen sijaan täydet sata. Näitä olivatesimerkiksilastenkulttuurikeskukset, tanssin aluekeskukset sekä ulkomailla sijaitsevat kulttuuri-instituutit. Avustusmuotoa kohden myöntöjen lukumäärä vaihteli 2:sta 168:aan. Keskimäärin myöntöjä oli 26 avustusmuotoa kohti.

Myöntöjen koko vaihteli suuresti sekä eri avustusmuotojen välillä että yksittäisten avustusmuotojen sisällä. Keskimääräinen myöntö oli 50000 euroa (pienin 1000 euroa ja suurin 2 milj. euroa). Pieniä avustuksia myönnettiin esimerkiksi kulttuurilehdille sekä monikulttuuriseen toimintaan ja rasismin vastaiseen työhön. Kulttuuritapahtuma-avustusten vaihteluväli oli 2 000:sta 740000 euroon. Isoja avustuksia myönnettiin taiteenalojen tiedotuskeskusten toimintaan sekä kulttuuritilojen peruskorjauksiin ja perustamishankkeisiin. Tila-avustukset ovat investointiavustuksia, tiedotuskeskukset puolestaan jakavat osan avustuksestaan edelleen muille toimijoille.

\section{Yleisluonnehdinta strategisuudesta}

Tutkijatiimin päällimmäinen havainto OKM:n hallinnassa olevien kulttuuriavustusten kokonaisuudesta oli, että se on laaja, moniulotteinen ja hajanainen. Strategisia linjauksia siitä on vaikea havaita. Erilaisia avustusmuotoja on ei-julkisessa haussa olevat avustukset sekä delegoidut määrärahat mukaan lukien - yhteensä jopa sata ${ }^{19}$. Yleistasolla OKM:n avustustoimintaa ja sen kehittämistä kulttuurin alueella leimaa koordinoimattomuus. Vuonna 2013 vastuu avustuskokonaisuudesta jakaantui 17 esittelevälle virkamiehelle, joista kukin toimii melko itsenäisesti. Osaa avustusmuodoista on viime vuosina työstetty niin hallinnollisesta kuin strategisestakin näkökulmasta, mutta vir- kamiehet ovat tehneet kehittämistyötä irrallaan kokonaisuudesta.

Koordinoimattomuus näkyi verkkosivujen hakutiedotuksesta, joka oli vuoden 2013 lopulla epäyhtenäistä. Hakuilmoitukset antoivat vaihtelevassa määrin tietoa avustusten tarkoituksista sekä kytkennöistä ministeriön strategiaan, ohjelmiin tai linjauksiin. Joissakin avustusmuodoissa hakijaa ohjattiin erilaisin käytännöin varsin tarkoin. Välineinä ohjauksessa käytetään esimerkiksi erillisiä lisäohjeita, lisätietolomakkeita, arviointikriteerejä tarkentavia muistioita sekä aiheeseen liittyviä erillisselvityksiä tai ohjelmia. Enimmillään informaatio-ohjausta voi olla yhteenlaskettuna satoja sivuja. Toisessa ääripäässä olivat avustusmuodot, joista tiedotettiin niin ylimalkaisesti, että järjestelmää tuntematon ei voinut hahmottaa avustuksen tarkoitusta tai hakukriteereitä.

Valtionavustukset kuuluvat Suomen kulttuuripolitiikan vanhimpiin välineisiin, ja niiden moninaisuus selittyy pitkälti historiallisesta kehityksestä. Järjestelmä on ajan myötä kumuloitunut ja sisältää erilaisten kulttuuripoliittisten ideologioiden pohjalta syntyneitä osasia. Vanhimmat toimialan valtionavustuksista ovat peräisin 1800-luvulla, tuoreimmat ovat viime vuosien ohjelmatyön tuotteita; otsikoiden tasolla avustusmuodot vaihtelevat yleisluontoisista toiminta-avustuksista tiukasti suunnattuihin erityisavustuksiin. (Suomalaisen kulttuuripolitiikan kehitysvaiheista ks. esim. Heiskanen, 1994; Kangas, 1999; kumulatiivisuudesta ks. Sokka \& Kangas, 2007.)

\section{Tapausanalyysien anti}

Tarkempaan analyysiin valittiin kuusi avustusmuotoa yleiskartoituksen havaintojen perusteella (Taulukko 1). Valintakriteereinä olivat mm. avustusmuodon historia, avustuslaji, määrärahan suuruus, myöntöjen ja hakemusten suhde sekä avustuksensaajien lukumäärä ja vakiintuneisuus. Tapauksia pyrittiin ottamaan kulttuuripolitiikan eri osa- ja tavoitealueilta. Avustusmuodon kuvauksessa ja ohjeistuksessa ilmaistuun strategisuuteen (tai sen puutteeseen) kiinnitettiin valinnassa huomiota. Lisäksi pidet- 
tiin tärkeänä saada joukkoon avustusmuotoja, joissa oli kokeiltu standardin yli meneviä erillisohjeita tai lomakkeita. Kuten aiemmin totesin, tapausten valintaan vaikutti niin ikään se, oliko avustusmuodosta tehty aiemmin arviointeja tai selvityksiä, joita oli mahdollista hyödyntää.

Tapausanalyysiin valittujen avustusmuotojen strategisuus vaihteli hakusivujen kuvauksissa suuresti. Kuvataidejärjestöjen avustuksia ei hakuilmoituksessa kytketty lainkaan kulttuuripoliittisiin ohjelmiin, kun taas kulttuuriviennin kärkihankeavustukset olivat, kuten jo otsikko kertoo, läpeensä strategisia. Järjestöavustukset ovat syntyneet jo ennen varsinaista kulttuuripolitiikkaa, vientiavustukset ovat sen sijaan ohjelma-aikakauden tuotteita. Kulttuuritapahtuma-avustukset puolestaan edustavat sellaista määrärahaa, jota on muokattu vastaamaan paremmin hallinnonalan ja valtion ohjausjärjestelmän linjauksia. Hakuun laadittiin vuonna 2012 liki 10-sivuinen erillisohje. Kulttuurivientiavustusten haussa sen sijaan edellytettiin vaikuttavuutta korostavaa liitelomaketta. Myös erikoismuseoilta, lastenkulttuurikeskuksilta ja kulttuuri-instituuteilta vaadittiin liiteasiakirjaa.

Tapausten joukossa oli avustusmuotoja, joissa kaikki hakijat saivat avustuksen ja kohderyhmä saatettiin jopa nimetä hakusivulla. Tällöin oli kyse avustusmuodosta, jonka käyttöä OKM ohjaa tarkoin. Kulttuuri-instituuttien ja lastenkulttuurikeskusten toiminta on ollut vahvasti OKM:n koordinoimaa. Instituuttien toimintaavustuksen hakuilmoituksessa mainitaan hakijasubjektit nimeltä ja avustuksen tarkoitusta

\begin{tabular}{|c|c|}
\hline Avustuksen nimi (yleis/erityisavustus) & Perustelut \\
\hline Kulttuuriviennin kärkihankkeet (E) & $\begin{array}{l}\text { Uudehko strateginen, ohjelmaperäinen hankeavustus; } \\
\text { matalahko myöntöprosentti; vaikuttavuutta korostava } \\
\text { erillislomake hakua varten; poikkihallinnollinen asi- } \\
\text { antuntijaryhmä; kulttuurivientiohjelma arvioitu } 2011\end{array}$ \\
\hline Lastenkulttuurikeskukset (Y) & $\begin{array}{l}\text { Vahva, ohjelmaperustainen OKM-ohjaus; myöntö- } \\
\text { prosentti 100; hakukriteereitä uudistettu äskettäin; } \\
\text { liiteasiakirjavaatimus; aiempia selvityksiä }\end{array}$ \\
\hline Suomen ulkomailla toimivat kulttuuri-instituutit (Y) & $\begin{array}{l}\text { Suuri määräraha; uvdelleen linjattu avustusmuoto; } \\
\text { rajattu hakija- ja saajajoukko; myöntöprosentti 100; } \\
\text { liiteasiakirjavaatimus; aiempia selvityksiä }\end{array}$ \\
\hline Valtakunnalliset erikoismuseot (Y, E) & $\begin{array}{l}\text { Suuri määräraha; pieni, melko vakiintunut saaja- } \\
\text { joukko, korkea myöntöprosentti; hakukelpoisuus } \\
\text { erityislakiin nojaavan OKM:n päätöksen rajaama; } \\
\text { liiteasiakirjavaatimus; aiempia selvityksiä }\end{array}$ \\
\hline Valtakunnalliset kuvataidealan järjestö† $(\mathrm{Y})$ & $\begin{array}{l}\text { Perinteinen avustusmuoto, ei uusia linjauksia; pieneh- } \\
\text { kö hakijamäärä, korkea myöntöprosentti; lausunto } \\
\text { Taikelta (mahdollinen delegointi) }\end{array}$ \\
\hline Valtakunnalliset taide- ja kulttuuritapahtumat (Y) & $\begin{array}{l}\text { Suuri määräraha, iso ja moninainen saajajoukko; } \\
\text { 1960-luvulla syntynyt määräraha, joka linjattu uu- } \\
\text { delleen; erillinen hakuopas } 2012 \text {; lausunto Taikelta; } \\
\text { osittaisesta delegoinnista Taikelle keskusteltu useita } \\
\text { vuosia; aiempia selvityksiä }\end{array}$ \\
\hline
\end{tabular}

Taulukko 1. Tapaustutkimuksen kohteeksi valitut avustusmuodot ja niiden valintaperusteet. 
kuvataan seuraavasti: "Kulttuuri-instituuttien toiminnalla edistetään Suomen kulttuurin ja tieteen alojen yhteistyötä Suomen ja asemamaan välillä ja luodaan edellytyksiä kulttuuriviennille ottaen huomioon hallitusohjelman ja hallituksen strategia-asiakirjan linjaukset, opetus- ja kulttuuriministeriön strategioissaan, toimintaohjelmissaan ja vuotuisessa tulossuunnitelmassaan määrittelemät tavoitteet sekä kansainvälisen yhteistyön muuttuvat tarpeet." (Ks. myös Opetusministeriö, 2005.)

Lastenkulttuurikeskusavustus syntyi vuonna 2003 kytköksissä OKM:n ensimmäiseen lastenkulttuuripoliittiseen ohjelmaan. OKM perusti lastenkulttuurikeskusten Taikalamppuverkoston, jonka jäsenet se valitsi. Ministeriö myös vahvisti kullekin keskukselle omat kehittämistehtävät, kuten valtakunnallisen vastuun jostain taidealasta tai kohderyhmästä. Vuoteen 2013 saakka ainoastaan Taikalampun jäsenet voivat hakea ja saada ministeriön avustusta toimintaansa. Syksyllä 2013 avustusmuotoa alettiin uudistaa suuntaan, joka löyhensi OKM:n ohjausotetta ja sidettä verkostoon. Arvioinneissa oli todettu mm., että verkosto ei ollut saavuttanut valtakunnallista kattavuutta (Berden, henkilökohtainen tiedonanto, 17. 6. 2014). Hakukriteerien muutokset näkyivät vuoden 2014 jakolistassa: otsikossa ei enää mainittu Taikalamppua ja saajien lukumäärä nousi 11:stä 15:een.

Osalle avustusmuodoista on muotoutunut ajan mittaan vakiintunut saajajoukko, vaikka tiukkaa ohjelmaohjausta ei ole. Tämä koskee esimerkiksi monien alojen järjestöavustuksia, joiden kuvauksissa kulttuuripoliittiset viittaukset ovat heikkoja. Perusteena avustuksen myöntämiselle toistuvasti samoille tahoille voi olla pyrkimys turvata tärkeänä pidetyn toiminnan jatkuvuus. Silti herää kysymys, kuinka perusteellisesti vakiintuneiden avustuksensaajien hakemuksia käydään läpi. Selvityksemme kannalta olennaisempaa on, kuinka pitkälle päätösesityksiä tehtäessä otetaan huomioon kulloisetkin strategiset linjaukset ${ }^{20}$. Jos rahat osoitetaan jatkuvasti samoille tahoille, valtionavustusinstrumentti menettää kykyään tarttua ajankohtaisiin linjauksiin tai uusiin toimijoi- hin. Kulttuuritapahtuma-avustuksen tavoitekuvausta ja ohjeistusta uudistettiin vuonna 2012, mutta saajajoukko pysyi osapuilleen entisellään. Tulkintamme mukaan vakiintuneiden avustuksensaajien toimintaa pyrittiin suuntaamaan informaatio-ohjauksen avulla uusille urille.

Avustus valtakunnallisten erikoismuseoiden erityistehtäviin oli vaikeaselkoinen. Valtionosuuden piirissä oleville - vieläpä korotettua valtionosuutta nauttiville - museoille myönnetään veikkausvoittovaroista lisäavustusta "valtakunnallisten erityistehtävien hoitamista" varten. Sulkeutuneisuutta lisäsi se, että hakusivuille ei ollut viety edellisten vuosien jakopäätöksiä. OKM:n rekisterin perusteella eräiden museoiden saamat avustussummat olivat huomattavia, jopa suurempia kuin niiden saamat valtionosuudet. Kallion (2012, s. 106) mukaan avustusmuoto syntyi museoiden valtionosuusjärjestelmää luotaessa 1990-luvun alussa, jotta eräiden rahoitusasemansa jo vakiinnuttaneiden museoiden tilanne ei olisi heikentynyt. Avustusmuodon esittelijältä saatiin tietää, että sitä kehitettiin jo ministeriössä Kallion selvityksen pohjalta läpinäkyvämpään ja tavoitteellisempaan suuntaan (Salonen, sähköposti, 7. 1. 2014).

Tapausanalyysin aineistoon sisältyivät myös avustushakemukset sekä käyttöselvitykset. Perushakemuspaketti sisältää hakulomakkeen, avustuksenkäyttövuoden toimintasuunnitelman ja talousarvion sekä tuoreimman toimintakertomuksen ja tilinpäätöksen, perusselvityspaketti puolestaan koostuu avustuksenkäyttövuoden toimintakertomuksesta ja tilinpäätöksestä. Avustusmuodosta riippuen voidaan vaatia muita liitteitä. Vaikuttavuuden arviointiin ja ennakointiin asiakirjat tarjosivat puutteellisen ja epäyhtenäisen perustan. Kuvataidejärjestöjen materiaali oli melko yhdenmukaista toimijoiden samankaltaisuuden takia, lastenkulttuurikeskuksia puolestaan yhtenäisti OKM:n ohjaus raportointivaatimuksineen. Sen sijaan kulttuuritapahtuma-avustuksia koskevat asiapaperit olivat sisällöltään sekalaisia ${ }^{21}$. Osalla tapahtumanjärjestäjistä oli muutakin toimintaa eikä tapahtumia aina eritelty toimintakertomuksissa. Ylipäätään niiden laajuus, taso ja tarkkuus vaihtelivat niin suuresti, että vertailukelpoisuus 
jäi heikoksi. Toimintakertomus laaditaan avustuksensaajan (usein yhdistyksen) omaa vuosittaista hallinnollista käsittelyä varten eikä vaikuttavuuden arvioimiseksi.

Tapausaineiston perusteella OKM:n kannattaa panostaa hakuohjeistukseen ja lomakkeisiin vaikuttavuuden kontrolloimiseksi. Kun hakemuksen edellytetään ottavan kantaa kulttuuripoliittiseen vaikuttavuuteen, toimija joutuu jo etukäteen miettimään toimintansa laajempaa merkitystä - tai vähintäänkin omaksumaan vaikuttavuusretoriikan (retorisesta nihilismistä ks. Häyrynen, 2006, s. 127). Useimpiin kulttuurin toimialan avustusmuotoihin ei vielä tarkasteluajankohtana liittynyt tällaista ohjeistusta, niinpä hakemuksissa keskityttiin rahoitusvuoden toimintaan ja sen välittömiin tuotoksiin. Kulttuuripolitiikan retoriset käänteet näkyivät erityisen voimakkaasti kulttuuriviennin kärkihankeavus- tuksissa, joihin kohdistuvat hakemukset ja selvitykset muistuttivat promootiopaketteja.

\section{Kehittämisehdotukset}

Cuporessa tehtiin selvityksen pohjalta kulttuuri- ja taidepolitiikan osastolle joukko kehittämisehdotuksia avustustoiminnan vaikuttavuuden lisäämiseksi. Koska lähtökohtana olivat olemassa olevat käytännöt, monet tutkijatiimin kommenteista koskivat hallinnollis-teknisiä yksityiskohtia. Kiinnitimme esimerkiksi huomiota hakuilmoitusten epämääräisyyteen niinkin keskeisen seikan kuin hakukelpoisuuden määrittelyssä. Alla on tiivis luettelo keskeisistä ehdotuksistamme, joista osa päätyi koko OKM:n valtionavustustoimintaa pohtineen työryhmän mietintöön (2014) ja kulttuuri- ja taidepolitiikan osaston valtionavustustyöryhmän asetuskirjeeseen (2014):

Valtionavustuksille on nimettävä vastuuvirkamies, joka huolehtii haku- ja selvityskäytäntöjen tarkoituksenmukaisuudesta ja koordinoi avustustoiminnan kehittämistä kohti strategisesti linjattua avustuspolitiikkaa.

Avustustiedottamista on yhdenmukaistettava. Jokaisen valtionavustuksen hakusivulla on ilmaistava kytkentä ministeriön tai laajemmin valtioneuvoston strategisiin tavoitteisiin. Hakusivulla on annettava linkki teemasivulle, jolta löytyvät olennaiset aihetta koskevat kulttuuripoliittiset asiakirjat; teemasivulla puolestaan tulee viitata aihepiiriin liittyviin avustuksiin.

Hakulomakkeita ja -ohjeistusta on kehitettävä niin, että rahoitettavan toiminnan otaksutut välittömät vaikutukset sekä laajempi vaikuttavuus saadaan selkeästi esiin. Selvityskäytäntöjä tulee kehittää niin, että tavoitteiden toteutuminen voidaan helposti tarkistaa. Selvitysvaatimuksista on pidettävä kiinni ${ }^{22}$. Arviointimahdollisuuksia voidaan parantaa yhtenäistämällä toimintasuunnitelmia ja -kertomuksia. Malleja on suunniteltava avustuksensaajien kanssa yhteisen edun saavuttamiseksi.

Avustusmuotojen määrän vähentämistä määrärahoja yhdistämällä on harkittava, jotta kokonaiskuva selkiintyisi.

Mahdollisuuksia delegoida määrärahoja virastoille, laitoksille tai kolmannen sektorin toimijoille on punnittava. Ministeriö voi säilyttää päätösvallan itsellään esimerkiksi strategisesti merkittävimmiksi katsottujen kulttuuritapahtumien tapauksessa.

Mahdollisuutta myöntää useavuotisia yleisavustuksia on selvitettävä. Tällöin toimija esittelee hakemuksessaan pitkän ajan toimintaansa ja sen vaikutuksia. Arvioinnin yhteydessä voidaan vastaavasti paneutua perusteellisesti toiminnan tuloksellisuuteen ja vaikuttavuuteen. Monivuotiset rahoituspäätökset edellyttävät tavoitekeskustelukäytännön omaksumista, joskin kevennetyssä muodossa, jotta avustustoiminnan hallinnointikustannukset pysyvät kurissa.

Osa OKM:n haltuun jäävistä valtionavustusmäärärahoista varataan uusien avauksien tukemiseen. Strategisesti tärkeiksi katsotuille hankkeille voidaan perustaa ohjausryhmä, jossa on OKM:n edustus.

\section{Taulukko 2. Kehittämisehdotukset avustustoiminnan vaikuttavuuden lisäämiseksi.}




\section{Yhteenvetoa, pohdintaa ja jatkotutkimussuuntia}

Vaikuttavuus tarkoitti selvityksessämme muutosta kohti kulttuuripolitiikan päämääriä. Valtionavustustoiminnan tapauksessa kyseessä on laaja-alainen, monivaiheinen ja pitkäkestoinen prosessi, jossa on monia epävarmuustekijöitä. Pyrkiessään toteuttamaan kulttuuripolitiikalle asetettuja tavoitteita OKM joutuu nojaamaan toimijoihin, jotka eivät ole suoraan sen omistuksessa tai ohjauksessa. Toimijoilla ja niiden ylläpitäjillä voi olla toisenlaisia painotuksia ja päämääriä, ja niillä on myös muita rahoittajia omine toiveineen. Silloinkin kun kulttuuripoliittiset tavoitteet saavutetaan, monimutkaisten syy-seurausketjujen takia valtionavustusten merkitystä on vaikea todentaa.

Selvityksemme vahvisti käsitystä, että kulttuuripolitiikan vaikuttavuuden saavuttamista ja arviointia vaikeuttaa se, että valtion tavoitteita kulttuurin toimialalla ei ole asetettu riittävän selkeästi. Kulttuuripolitiikalle löytyy eri asiakirjoista runsaasti tavoitteita, mutta niitä ei ole selkeästi priorisoitu eikä kaikilta osin suhteutettu toisiinsa tai laajoihin yhteiskuntapoliittisiin tavoitteisiin. Tarkemmin analysoituna eri aikakausilta periytyneet kulttuuripoliittiset päämäärät saattavat osoittautua jopa keskenään ristiriitaisiksi (ks. Häyrynen, 2006, s. 125). Kulttuuripoliittisten tavoitteiden ja toimien yhteensopivuutta kunkin hallituskauden poliittisten tavoitteiden tai valtiokonserniohjauksen päämäärien kanssa olisi myös aihetta pohtia.

Suomalaisen valtionhallinnon ongelmana pidetty siiloutuneisuus (OECD, 2010, s. 28) nousi esiin selvitystä tehdessä. Kulttuuripolitiikan hallinnonala on siiloutunut ja jopa sen sisällä vaikuttaa olevan keskenään kommunikoimattomia saarekkeita, minkä arvelen selittävän osaltaan myös avustusjärjestelmän hajanaisuutta. Saman havainnon olen tehnyt aiemminkin taide- ja kulttuurihallintoon liittyvissä hankkeissa, joiden yhteydessä olen päässyt harjoittamaan eräänlaista hallinnon etnografi$\mathrm{aa}^{23}$ (ks. Karttunen, 2012). Kulttuurihallinnossa vastustetaan usein valtionhallinnon uudistuksia, joiden pelätään uhkaavan toimialan (tai oman toimintalohkon) erityisyyttä. Irtiottoa voimistaa hallintosektorin vahva kansainvälinen perusta ja taustayhteisö (ks. esim. Häyrynen, 2006, s. 126-127). Sieltä saa lisäpontta puhe "kulttuuripolitiikan syvärakenteista" (ks. Opetusministeriö, 2009b, s. 30), joiden vaikutus ylittää ohimenevät hallituskaudet.

Valtionavustusselvityksen perusteella OKM ei vaikuta ottaneen tiukan strategista roolia toimialansa johdossa. Jo määrällinen tarkastelu osoitti, että ministeriöllä itsellään on kulttuurin toimialalla vastuullaan yhä huomattava määrä operatiivista toimintaa. Kenties tilanne muuttuu, kun vuonna 2013 toimintansa aloittanut Taiteen edistämiskeskus vakiinnuttaa asemaansa taiteen keskusvirastona. Kun monet määrärahoista ovat pieniä ja useista määrärahoista myönnetään vaatimattomia avustuksia, on houkutuksena ehdottaa OKM:lle määrärahojen delegoimista tai yhdistämistä. Usein kuulee sanottavan, että parin tuhannen euron avustuksista on turha odottaa vaikuttavuutta ja että niiden myöntäminen ei ole kustannustehokasta. Joskus kuitenkin pienikin kynnysraha saa aikaan laajakantoisia vaikutuksia, eikä OKM:n tuen symbolista merkitystäkään ole syytä väheksyä. Muutoksille tulisi olla strateginen perustelu.

OKM näkee valtionavustukset kätevänä tapana synnyttää uusia, kohdennettuja tukimuotoja. Kulttuurin toimialalla onkin perustettu erilaisia avustusmuotoja vuosien mittaan runsaasti, jopa holtittomasti. Valtionavustusjärjestelmä on kumuloitunut ja sisältää poliittisideologisilta sidoksiltaan kirjavia aineksia. Valtionavustusten perustamisen helppous voi siis tuottaa kääntöpuolenaan tukijärjestelmään rakenteellista jäykkyyttä ja sisällöllistä ristiriitaa. Tietyin määräajoin olisikin syytä arvioida kunkin avustusmuodon roolia ja tarvetta sekä avustuspolitiikan muodostamaa kokonaisuutta. Lisäksi valtionavustuksia olisi tarkasteltava muiden kulttuuripoliittisten instrumenttien kontekstissa.

Olen käyttänyt edellä useaan kertaan termejä "ohjausväline" ja "politiikkainstrumentti". Vaikka OKM:n toimeksianto oli aineistopohjainen pika-analyysi, hain kirjallisuudesta tukea 
valtionavustusten luonteen ymmärtämiseksi. Erityisen lupaavalta vaikutti lähestymistapa, johon viitataan englanniksi termeillä government tools approach, policy instrument approach ja policy design analysis (ks. esim. Hood, 1986; Howlett, 2005 \& 2011; Salamon, 2002). Suomeksi siitä on käytetty nimeä "ohjausvälineen näkökulma” (Oulasvirta, Ohtonen \& Stenvall, 2002, s. 15). Sitä hyödynnetään tyypillisesti suunniteltaessa uusia politiikkaohjelmia, mutta se sopii yhtä lailla historian saatossa muotoutuneen välineistön arviointiin. Valtionavustusselvityksessä lähestymistavasta sai heuristista tukea, minkä lisäksi se auttoi irrottautumaan suomalaisen empirian itsestäänselvyyksistä. Olisi kiehtovaa päästä rakentamaan tältä pohjalta valtion kulttuurirahoitusta ja -ohjausta koskevaa tutkimushanketta.

Ohjauskeinot luokitellaan usein pakotteisiin (eli keppeihin), kannusteisiin (porkkanoihin) ja informaatioon (saarnoihin) (ks. Bemelmans-Videc ym., 1998). Valtionavustukset voidaan määritellä positiivisiksi taloudellisiksi ohjauskeinoiksi eli kannusteiksi, joihin liittyy vaihteleva määrä informaatio-ohjausta (vrt. Vedung, 1997; Leeuw, 1998; Beam \& Conlan, 2002). Oletuksen mukaan liberaalissa demokratiassa korostetaan suostuttelevia keinoja hallinnan legitimiteetin varmistamiseksi (Vedung, 1997, s. 40-41). OKM:ssä onkin viime aikoina puhuttu neuvottelevasta tai dialogisesta ohjauksesta. Vuorovaikutus rahoittajan ja rahoitettavan välillä voi kuitenkin siirtää valtionavustustoimintaa suoran ohjauksen suuntaan, vaikka valtionavustukset on perinteisesti ymmärretty epäsuoran, etäisyyttä ottavan ohjauksen lajiksi. Toimittaessa itsenäisten kansalaisyhteiskunnan toimijoiden tai kuntien kanssa tilanne on herkkä. Kysymys taiteen autonomiasta voi myös nousta esiin, mihin Cupore kiinnitti huomiota OKM:lle tehdyssä raportissa. Lisäksi on huomattava, että tällä hetkellä minkään tyyppiselle tavoiteohjaukselle ei ole juridista pohjaa.

Yksittäisen rahoitusinstrumentin pintapuolinenkin analyysi - yhdistettynä epäsystemaattiseen hallinnon etnografiaan - voi avata kiinnostavia näkymiä kulttuuripolitiikan ja -hallinnon rakenteisiin ja toimintaan. On suorastaan hämmästyttävää, kuinka vähän Suomessa on tutkittu valtion ohjausjärjestelmän rajujen muutosten vaikutusta kulttuuripolitiikkaan. Uusliberalistiseen retoriikkaan on kiinnitetty tutkimuksessa enemmän huomiota kuin konkreettisiin ohjauskäytäntöihin ja niiden vaikutuksiin. Itseäni jäi kovasti askarruttamaan kysymys OKM:n roolista kulttuuripolitiikan suunnan määrittelyssä: mihin poliittisiin asiakirjoihin toimialan ohjauksen pitäisi perustua ja mitä todellisuudessa tapahtuu?

\section{Kirjallisuus}

Beam, D. R. \& Conlan, T. J. (2002). Grants. Teoksessa L. M. Salamon (toim.), The Tools of Government (340-380). New York: Oxford University Press.

Bemelmans-Videc, M.-L., Rist, L. C. \& Vedung, E. (toim.) (1998). Carrots, Sticks and Sermons. New Brunswick: Transaction.

Granö, P., Korkeakoski, E. \& Laukka, M. (2006). Taikalamppujen valossa. Opetusministeriön työryhmämuistioita ja selvityksiä 2006:25. Helsinki: OKM.
Heiskanen, I. (1994). Kulttuuripolitiikan pitkät linjat. Hyvinvointikatsaus, 2/94, 6-9.

Hood, C. (1986). The Tools of Government. Chatham: Chatham House.

Howlett, M. (2005). What is a Policy Instrument? Teoksessa P. Eliadis ym. (toim), Designing Government (31-50). Montreal: McGill-Queen's University Press.

Howlett, M. (2011). Designing Public Policies. New York: Routledge. 
Häyrynen, S. (2006). Suomalaisen yhteiskunnan kulttuuripolitiikka. Jyväskylä: SoPhi.

Kallio, K. (2012). Valtakunnalliset erikoismuseot. Opetus- ja kulttuuriministeriön julkaisuja 201 2:27. Helsinki: OKM.

Kangas, A. (1999). Kulttuuripolitiikan uudet vaatteet. Teoksessa A. Kangas \& J. Virkki (toim.), Kulttuuripolitiikan undet vaatteet (156-178). Jyväskylä: SoPhi.

Karttunen, S. (2012). Cultural policy indicators. Cultural Trends, 21 (1), 1-15.

Karttunen, S., Kontkanen, R. \& Saukkonen, P. (2014). Opetus- ja kulttuuriministeriön kulttuuriin ja taiteeseen liittyvät valtionavustukset. Opetus- ja kulttuuriministeriölle 13.1 1.2014 luovutettu raportti (julkaisematon). Helsinki: Kulttuuripoliittisen tutkimuksen edistämissäätiö.

Kontkanen, R., Saukkonen, P. \& Mitchell, R. (2012). Vientiä, vaihtoa, vaikuttavuutta. Cuporen verkkojulkaisuja 12. Helsinki: Kulttuuripoliittisen tutkimuksen edistämissäätiö.

Korkeakoski, E. \& Pääjoki, T. (2009). Taikalamppujen loisteessa. Opetusministeriön julkaisuja 2009:24. Helsinki: OKM.

Leeuw, F. L. (1998). The Carrot: Subsidies as a Tool of Government. Teoksessa M.-L. Bemelmans-Videc ym. (toim.), Carrots, Sticks and Sermons (77-102). New Brunswick: Transaction.

OECD (2010). OECD Public Governance Reviews: Finland. OECDpublishing.

Opetus- ja kulttuuriministeriön kulttuuriin ja taiteeseen liittyvät avustukset (s. d.). Opetusja kulttuuriministeriön verkkosivusto. URL: http://www.minedu.fi/OPM/Avustukset/ Kulttuuri? lang =fi (haettu 2. 12. 2013)

Opetus- ja kulttuuriministeriö (201 1a). Kulttuuritapahtumien avustusjäriestelmän uudistaminen. Opetus- ja kulttuuriministeriön työryhmämuistioita ja selvityksiä 201 1:24. Helsinki: OKM.

Opetus- ja kulttuuriministeriö (2011b). Kulttuurivienti näkyy, uudistaa ja vaikuttaa. Opetusja kulttuuriministeriön julkaisuja 2011:20. Helsinki: OKM.

Opetus- ja kulttuuriministeriö (2011c). Yhdessä enemmän - selvitys opetus- ja kulttuuriministeriön konserniohjauksesta ja -rakenteesta. Opetus- ja kulttuuriministeriön työryhmämuistioita ja selvityksiä 2011 1:6. Helsinki: OKM.

Opetus- ja kulttuuriministeriö (2014). Valtionavustusten käytäntöjen ja vaikuttavuuden kehittäminen. Opetus- ja kulttuuriministeriön työryhmämuistioita ja selvityksiä 2014:24. Helsinki: OKM.

Opetusministeriö (2005). Strategiset linjaukset kulttuuri- ja tiedeinstituuttien tukemiselle. Ope- tusministeriön työryhmämuistioita ja selvityksiö 2005:26. Helsinki: OKM.

Opetusministeriö (2007). Onko kulttuurilla vientiä? Opetusministeriön julkaisuja 2007:9. Helsinki: OKM.

Opetusministeriö (2009a). Kulttuuripolitiikan strategia 2020. Opetusministeriön julkaisuja 2009:1 2. Helsinki: OKM.

Opetusministeriö (2009b). Vaikuttavuusindikaattorit kulttuuripolitiikan tietopohian vahvistajina. Opetusministeriön julkaisuja 2009:57. Helsinki: OKM.

Oulasvirta, L., Ohtonen, J. \& Stenvall, J. (2002). Kuntien sosiaali- ja terveydenhuollon ohjaus. Sosiaali- ja terveysministeriön julkaisuja 2002:19. Helsinki: STM.

Rajahonka, M. (2013). Vuorovaikutuksessa vaikuttamiseen. Helsinki: Aalto-yliopisto.

Rautiainen, P. (2010). Valtion tuki kulttuuritapahtumille 2000-2008. Työpapereita 48. Helsinki: Taiteen keskustoimikunta.

Salamon, L. M. (toim.) (2002). The Tools of Government. New York: Oxford University Press.

Sokka, S. \& Kangas, A. (2007). At the Roots of Finnish Cultural Policy. International Journal of Cultural Policy, 13 (2), 185-202.

Valtiontalouden tarkastusvirasto (2004). Valtionavustuslain ohjausvaikutus. Tarkastuskertomus 88/2004. Helsinki: VTV.

Valtiontalouden tarkastusvirasto (2012). Avustukset veikkauksen ja raha-arpajaisten voittovaroista urheilun ja liikuntakasvatuksen, tieteen, taiteen ja nuorisotyön edistämiseen. Valtiontalouden tarkastusviraston tarkastuskertomukset 14/2012. Helsinki: VTV.

Valtiovarainministeriö (2003). Parempaan tilivelvollisuuteen. Työryhmämuistioita 2/2003. Helsinki: VM.

Valtiovarainministeriö (2006). Ministeriöiden kustannuslaskennan kehittäminen. Ohjaus ja tilivelvollisuus 1/2006. Helsinki: VM.

Valtiovarainministeriö (2012). Kohti strategisempaa, kevyempää, poikkihallinnollisempaa ja yhtenäisempää tulosohjausta. Valtiovarainministeriön julkaisuja 21/2012. Helsinki: VM.

Vedung, E. (1997). Policy Instruments. Teoksessa M.-L. Bemelmans-Videc ym. (toim.), Carrots, Sticks and Sermons (21-58). New Brunswick: Transaction. 


\section{Loppuviitteet}

1. Vuoden 2014 kevääseen saakka kulttuuri-, nuoriso- ja liikuntapolitiikan osasto.

2. Säätiö saa merkittävän osan toimintansa rahoituksesta valtionavustuksena kulttuuripolitiikan sektoritutkimukseen osoitetusta määrärahasta, jonka turvin toteutettavan tutkimuksen teemoista sovitaan vuosittaisissa tavoitekeskusteluissa. Lisäksi OKM tekee erillisiä tilauksia silloin, kun on kyseessä suora toimeksianto. 3. Tutkijoina hankkeessa toimivat eri ajankohtina Kaisa Herranen ja Riina Kontkanen.

4. Tähän on velvoittanut valtioneuvoston periaatepäätös (16.4. 1998), jonka mukaan ministeriöiden on pyrittävä keskittymään poliittisen päätöksenteon valmisteluun ja strategiseen johtamiseen.

5. OKM:n valtionavustustyöryhmän raportissa (2014, s. 26) luetellaan useita syitä sille, miksi jotkin avustusmuodot eivät ole julkisesti haettavissa. Selkeimpiin kuuluu se, että eduskunta on osoittanut määrärahan nimetylle taholle jo valtion talousarviossa (esim. Kansallisgalleria). 6. Luovan talouden ja kulttuuriyrittäjyyden erikoishankkeet oli delegoitu Audiovisuaalisen kulttuurin edistämiskeskukselle. Museoiden, teattereiden ja orkestereiden valtionosuudet sekä valtion ylimääräiset taiteilijaeläkkeet poistettiin, koska ne eivät kuulu valtionavustuslain soveltamisalan piiriin. Lisäksi ulkopuolelle jätettiin kolme lisätalousarvioihin perustuvaa avustusmuotoa.

7. Tiedoissa oli jonkin verran epäyhtenäisyyk- siä, joita piti tarkistaa. Taulukosta 1 näkyy, että osa niistä jäi avoimiksi. Poikkeamat olivat niin pieniä, että ne eivät vaikuta yleiskuvaan.

8. Avustuksista tiedotetaan nykyisin ainoastaan internetin välityksellä. Laki edellyttää valtionapuviranomaista tiedottamaan mahdollisuudesta hakea valtionavustusta "sopivalla tavalla". 9. Menettelytapaohje päivitettiin syksyllä 2013. Valtiontalouden tarkastusvirasto (2012, s. 69) oli huomauttanut tarpeesta päivittää vuodelta 1994 peräisin oleva ohje. Hakuilmoituksessa on mainittava $\mathrm{mm}$. seuraavat asiat: avustuksiin sovellettavat säädökset, avustusten käytölle asetetut tavoitteet, avustuskelpoiset kohderyhmät, avustuslaji, hakemusten määräaika, avustusten myöntämisen välttämättömät edellytykset, valintaperusteet, mahdollinen valtionavustusten enimmäisosuus hankkeen tai toiminnan hyväksytyistä kokonaiskustannuksista sekä mahdolliset avustusten laskennalliset perusteet.

10. Vuoden 2011 selvityksistä huomattava osa oli vuoden 2014 alussa yhä taloustarkastuksessa, josta niiden identifioiminen olisi ollut paitsi työlästä myös häiritsevää. Myöhemmin osoittautui, että osa vuoden 2010 materiaalistakin puuttui yhä arkistosta.

11. Ohjausryhmään kuului kaksi OKM:n virkamiestä, johtaja Tuula Lybeck ja kulttuuriasiainneuvos Esa Pirnes. Lisäksi oltiin yhteydessä valtionavustusten esittelijöihin sekä avustusasioita käsitteleviin, tarkastaviin ja arkistoiviin virkamiehiin. 
12. Työryhmää johtaa Tuula Lybeck, joka veti myös koko OKM:tä koskenutta selvitystä.

13. Valtionavustuslain mukaan erityisavustus voidaan myöntää 1) investointiavustuksena aineellisen tai aineettoman hyödykkeen hankintaan, 2) hankeavustuksena kokeilu-, käynnistämis-, tutkimus- tai kehittämishankkeeseen tai muuhun tarkoitukseltaan rajattuun hankkeeseen, 3) apurahana, stipendinä tai avustuksena hakijan henkilökohtaiseen käyttöön tai hankkeeseen tai 4) muuna 1-3 kohdassa tarkoitettuun verrattavana erityisavustuksena.

14. Tässä ei siis käytetä termiä vaikuttavuus.

Osa luettelossa mainituista seikoista on selkeästi vaikutusten arviointia, jota usein edellytetään tehtäväksi ennen toimenpiteisiin ryhtymistä. 15. Tähän eivät sisälly lakisääteiset apurahat taiteilijoille, kirjailijoille ja kääntäjille eivätkä valtionosuudet teattereille, orkestereille ja museoille (Opetus- ja kulttuuriministeriö 2014, s. 16, alaviite 4$)$.

16. Tulosprisma on sittemmin uudistettu kolmiulotteiseksi kartiomalliksi, jonka katsotaan paremmin kuvaavan hallintosektorien rajat hälventävää konserniohjausmallia (Valtiovarainministeriö 2012, s. 16).

17. Vuonna 2013 OKM:stä myönnettiin

kulttuurin toimialalla (Taide ja kulttuuri, 29.80) yhteensä 1420 valtionavustusta. Euromääräisesti myönnöt olivat yhteensä noin 187,7 miljoonaa. (Opetus- ja kulttuuriministeriö, 2014, s. 13.)

18. Pääosa maailmanperintökohteisiin tar- koitetusta määrärahasta oli asetettu käyttöön Museovirastolle, joka myöntää niitä edelleen entistämisavustuksina.

19. Kokonaiskatsausta kulttuurialan valtionavustuksista ei tiettävästi ole tehty nykyisen valtionavustuslain aikana. Kulttuuri- ja taidepolitiikan osaston vuonna 2014 asettama työryhmä on parhaillaan laatimassa sellaista.

20. Asiaa voitaisiin tutkia esimerkiksi analysoimalla ministerille tehtyjä esittelymuistioita, joita tässä selvityksessä ei ollut mahdollisuutta käydä systemaattisesti läpi.

21. Tässä puhutaan vuoden 2010 asiakirjoista. Erillisohje hakuun tehtiin vuonna 2012.

22. Valtiontalouden tarkastusvirasto (2012, s. 69) huomautti, että OKM:n hyväksymät selvitykset olivat usein puutteellisia eikä niiden avulla ollut mahdollista varmistua avustuksen asianmukaisesta käytöstä.

23. Materiaalin käyttäminen tutkimustarkoituksiin on ongelmallista, koska osa kiinnostavista havainnoista ei useinkaan liity varsinaiseen selvitystehtävään vaan syntyy prosessin sivutuotteena. Valtionavustushankkeessa on tutkimuseettisesti merkille pantavaa, että saimme OKM:n ja Cuporen välisen luottamussuhteen ansiosta poikkeuksellisen vapaan pääsyn ministeriön toimitiloihin ja tietokantoihin sekä mahdollisuuden jututtaa henkilöstöä. Suhtautumiseen vaikutti myös se, että teimme suoraa toimeksiantoa OKM:lle. 
Liite 1. Selvityksen kohteena olleet valtionavustukset 2013.

\begin{tabular}{|c|c|c|c|c|c|c|}
\hline AVUSTUSMUODON NIMI & $\begin{array}{l}\text { Avustuslaji } \\
\text { (yleis/ } \\
\text { erityis) }\end{array}$ & $\begin{array}{l}\text { Mäc̈räraha } \\
(1000 €)\end{array}$ & $\begin{array}{l}\text { Hakemuk- } \\
\text { sia (kpl) }\end{array}$ & $\begin{array}{l}\text { Hyväksyłty } \\
\text { (kpl) }\end{array}$ & Myöntö-\% & $\begin{array}{l}\text { Vaihteluväli } \\
(1000 €)\end{array}$ \\
\hline $\begin{array}{l}\text { Avustus kulttuuriviennin hank- } \\
\text { keisiin, painopisteenä Kiinan } \\
\text { ja Aasian kulttuuriviennin } \\
\text { edistäminen* }\end{array}$ & $E$ & 750 & 33 & 14 & 42 & $15-190$ \\
\hline $\begin{array}{l}\text { Jean Sibeliuksen juhlavuosi } \\
2015^{*}\end{array}$ & $\mathrm{E}$ & 500 & 29 & 17 & 59 & $20-55$ \\
\hline Kulttuurilehdet*• & Y & 1093 & 178 & 151 & 85 & $1-67$ \\
\hline $\begin{array}{l}\text { Kulttuurin matkailullinen tuot- } \\
\text { teistaminen*• }\end{array}$ & $\mathrm{E}$ & 713 & 97 & 33 & 34 & $10-60$ \\
\hline $\begin{array}{l}\text { Kulttuurinen ulkosuomalaistoi- } \\
\text { minta }\end{array}$ & Y & 935 & 6 & 4 & 67 & $40-570$ \\
\hline $\begin{array}{l}\text { Kulttuuritilojen peruskorjaukset } \\
\text { ja perustamishankkeet* }\end{array}$ & E & 6650 & 20 & 11 & 55 & $25-2000$ \\
\hline $\begin{array}{l}\text { Kulttuuriviennin hankkeiden } \\
\text { hankevalmistelu* }\end{array}$ & $E$ & 145 & 37 & 8 & 22 & $10-29$ \\
\hline $\begin{array}{l}\text { Kulttuuriviennin kärkihank- } \\
\text { keet* }\end{array}$ & $\mathrm{E}$ & 1481 & 90 & 23 & 26 & $20-265$ \\
\hline $\begin{array}{l}\text { Kuntien kulttuuritoiminnan } \\
\text { kehittämis- ja kokeilutoiminta } \\
\text { sekä erityistehtävät* }\end{array}$ & $E$ & 106 & 159 & 4 & 3 & $10-36$ \\
\hline Lastenkulttuurikeskukset*• & Y & 1285 & 11 & 11 & 100 & $75-200$ \\
\hline $\begin{array}{l}\text { Maailmanperintökohteiden } \\
\text { tutkimus- ja valistustoiminta* }\end{array}$ & $E$ & 23 & 2 & 2 & 100 & $3-20$ \\
\hline $\begin{array}{l}\text { Mediakasvatuksen kehittä- } \\
\text { minen* }\end{array}$ & $E$ & 854 & 31 & 17 & 55 & $9-150$ \\
\hline $\begin{array}{l}\text { Mediataiteenalan valtakun- } \\
\text { nalliset järjestöt* }\end{array}$ & $Y$ & 216 & 5 & 4 & 80 & $18-86$ \\
\hline $\begin{array}{l}\text { Monikulttuurisuuden tukeminen } \\
\text { ¡a rasismin vastainen työ* }\end{array}$ & $Y, E$ & 650 & 189 & 90 & 48 & $1-55$ \\
\hline Rauhantyön edistäminen & $Y, E$ & 560 & 29 & 23 & 79 & $1-180$ \\
\hline $\begin{array}{l}\text { Suomalais-ugrilainen kulttuu- } \\
\text { riyhteistyö Venäjän kanssa• }\end{array}$ & $E$ & 422 & 23 & 14 & 61 & $5-120$ \\
\hline $\begin{array}{l}\text { Suomen ulkomailla toimivat } \\
\text { kulttuuri-instituutit }\end{array}$ & Y & 4700 & 13 & 13 & 100 & 69-708 \\
\hline $\begin{array}{l}\text { Suomen ulkomailla toimivien } \\
\text { instituuttien kulttuurivienti- ja } \\
\text { kehittämishankkeet* }\end{array}$ & $\mathrm{E}$ & 531 & 25 & 20 & 80 & $3-48$ \\
\hline $\begin{array}{l}\text { Säveltaidetta tai sen harras- } \\
\text { tamista edistävät valtakunnal- } \\
\text { liset järjestöt ja musiikki-ins- } \\
\text { tituutit* }\end{array}$ & Y & 1500 & 32 & 28 & 88 & $3-273$ \\
\hline $\begin{array}{l}\text { Taiteen ja kulttuurin kehit- } \\
\text { tämishankkeet kunnissa ja } \\
\text { alueilla* }\end{array}$ & $\mathrm{E}$ & 1000 & 159 & 29 & 18 & $10-90$ \\
\hline $\begin{array}{l}\text { Taiteen ja kulttuurin Venä- } \\
\text { ¡ä-ohjelman toimeenpano* }\end{array}$ & $E$ & 540 & 64 & 42 & 66 & $1-58$ \\
\hline $\begin{array}{l}\text { Taiteen ja kulttuurin yleiset } \\
\text { projektit* }\end{array}$ & $\mathrm{E}$ & 3651 & 109 & 67 & 61 & $3-757$ \\
\hline
\end{tabular}




\begin{tabular}{|c|c|c|c|c|c|c|}
\hline AVUSTUSMUODON NIMI & $\begin{array}{l}\text { Avustuslaji } \\
\text { (yleis/ } \\
\text { erityis) }\end{array}$ & $\begin{array}{l}\text { Määräraha } \\
(1000 €)\end{array}$ & $\begin{array}{l}\text { Hakemuk- } \\
\text { sia (kpl) }\end{array}$ & $\begin{array}{l}\text { Hyväksytty } \\
\text { (kpl) }\end{array}$ & Myöntö-\% & $\begin{array}{l}\text { Vaihteluväli } \\
(1000 €)\end{array}$ \\
\hline $\begin{array}{l}\text { Taiteenalojen tiedotuskes- } \\
\text { kusten toiminta ja ulkomaille } \\
\text { suunnatut kulttuurilehdet* }\end{array}$ & $\mathrm{Y}, \mathrm{E}$ & 4103 & 14 & 9 & 64 & $65-1000$ \\
\hline $\begin{array}{l}\text { Taiteilijoiden toimeentulon ja } \\
\text { työllisyyden kehittäminen sekä } \\
\text { vapaan kentän tuki*• }\end{array}$ & $\mathrm{E}$ & 975 & 133 & 30 & 23 & $7-90$ \\
\hline Tanssin aluekeskukset* & $Y$ & 950 & 6 & 6 & 100 & $33-200$ \\
\hline $\begin{array}{l}\text { Valtakunnalliset kirjallisuuden } \\
\text { alan järjestöt, instituutit ja } \\
\text { kirjailijatalot* }\end{array}$ & Y & 865 & 18 & 16 & 89 & $3-152$ \\
\hline $\begin{array}{l}\text { Valtakunnalliset kuvataide- } \\
\text { järjestöt* }\end{array}$ & Y & 450 & 14 & 13 & 93 & $3-145$ \\
\hline $\begin{array}{l}\text { Valtakunnalliset muotoilualan } \\
\text { järiestöt* }\end{array}$ & $Y$ & 436 & 8 & 8 & 100 & $9-293$ \\
\hline $\begin{array}{l}\text { Valtakunnalliset museo- ja } \\
\text { kulttuuriperintöalan järjestöt* }\end{array}$ & $Y$ & 860 & 12 & 12 & 100 & $10-275$ \\
\hline $\begin{array}{l}\text { Valtakunnalliset näyttämötai- } \\
\text { dejärjestöt* }\end{array}$ & Y & 668 & 15 & 14 & 93 & $4-237$ \\
\hline $\begin{array}{l}\text { Valtakunnalliset rakennustai- } \\
\text { teen alan järjestöt* }\end{array}$ & Y & 100 & 5 & 5 & 100 & $5-40$ \\
\hline $\begin{array}{l}\text { Valtakunnalliset sarjaku- } \\
\text { va-alan järjestöt** }\end{array}$ & Y & 100 & 3 & 3 & 100 & $5-85$ \\
\hline $\begin{array}{l}\text { Valtakunnalliset taide- ja } \\
\text { kulttuuritapahtumat* }\end{array}$ & $Y$ & 5150 & 238 & 168 & 71 & $2-740$ \\
\hline $\begin{array}{l}\text { Valtakunnalliset tanssitaide- } \\
\text { ¡ärjestöt* }\end{array}$ & Y & 84 & 5 & 5 & 100 & $6-29$ \\
\hline $\begin{array}{l}\text { Valtakunnalliset valoku- } \\
\text { va-alan järjestöt** }\end{array}$ & Y & 140 & 3 & 3 & 100 & $11-108$ \\
\hline $\begin{array}{l}\text { Valtakunnallisille elokuva- ja } \\
\text { audiovisuaalisen kulttuurin } \\
\text { järjestöille* }\end{array}$ & $Y$ & 440 & 15 & 11 & 73 & $6-145$ \\
\hline $\begin{array}{l}\text { Valtakunnallisten erikoismuse- } \\
\text { oiden toiminta*. }\end{array}$ & $Y$ & 4000 & 27 & 20 & 74 & $25-580$ \\
\hline $\begin{array}{l}\text { Valtionosuuden piirissä olevat } \\
\text { valtakunnalliset tai alueelli- } \\
\text { sesti merkittävät teatterit tai } \\
\text { orkesterit ja teattereiden tai } \\
\text { orkestereiden kehittämishank- } \\
\text { keet* }\end{array}$ & $Y, E$ & 3990 & 53 & 31 & 58 & $8-350$ \\
\hline $\begin{array}{l}\text { Vammaisyhteisöjen kulttuuri- } \\
\text { toiminta ja kulttuurin saavutet- } \\
\text { tavuuden edistäminen* }\end{array}$ & $Y, E$ & 715 & 102 & 31 & 30 & $4-135$ \\
\hline Ystävyysseurat• & $Y$ & 2000 & 36 & 30 & 83 & $1-1122$ \\
\hline YHTEENSÄ & & 54832 & 2135 & 1066 & 50 & $1-2000$ \\
\hline
\end{tabular}

* Rahoitettu veikkausvoittovaramomentilta 29.80.52.

- OKM:n Salama-rekisterin tiedot määrärahan käytöstä poikkeavat jonkin verran avustusmuodon verkkosivulla julkaistusta jakolistasta tai esittelijän sähköpostitse antamista tiedoista.

Lähteet: OKM:n verkkosivut; SALAMA-rekisteri; avustuksista vastaavat virkamiehet. 